\title{
Simple Sequence Repeat Markers Reveal Hungarian Plum (Prunus domestica L.) Germplasm as a Valuable Gene Resource
}

\author{
Noémi Makovics-Zsohár \\ Department of Genetics and Plant Breeding, Szent István University, \\ Budapest, Hungary \\ Magdolna Tóth \\ Almakúti Agricultural Company, Zalaszántó, Hungary
}

\begin{abstract}
Dezső Surányi
National Agricultural Research and Innovation Center, Fruitculture Research Institute, Research Station of Cegléd, Hungary

Szilvia Kovács

National Agricultural Research and Innovation Center, Fruitculture Research Institute, Research Station of Érd, Hungary
\end{abstract}

Attila Hegedüs ${ }^{1}$ and Júlia Halász ${ }^{1}$

Department of Genetics and Plant Breeding, Szent István University, Budapest, Hungary

Additional index words. breeding, DNA fingerprint, fruit, genetic diversity, landrace, microsatellite markers, PCA

\begin{abstract}
The hexaploid European plum (Prunus domestica L.) is an economically important fruit species with limited information on its genetic structure. Our objective was to fingerprint 55 cultivars using seven simple sequence repeat (SSR) markers to estimate the polymorphism level and determine allelic variation and genetic relationships among local and international cultivars. The primer pairs amplified a total of 135 alleles ranging from six to 27 alleles per locus, displaying high polymorphism. All genotypes were clearly distinguished with the seven SSRs used in this study. In a neighbor-joining cluster analysis, cultivars belonging to the same species did not group together. Foreign modern cultivars clustered together, and Hungarian landraces positioned distantly from those. STRUCTURE analysis indicated three genetically distinct groups of the studied genotypes. Each cluster of Hungarian landrace cultivars received strong bootstrap support $(89 \%$ to $100 \%)$. Most genotypes kept under identical name showed different DNA fingerprints. A principal component analysis (PCA) confirmed the information provided by the dendrogram and clarified the origin of 'Fehérszilva'. Our results confirmed the potential of the application of SSR markers in plum breeding.
\end{abstract}

European plum (Prunus domestica L.) is an economically important temperate fruit species and was one of the first crops that attracted human interest (Faust and Surányi, 1999). Its fruits are very popular because it can be used for several purposes, such as for

Received for publication 15 Aug. 2017. Accepted for publication 11 Sept. 2017.

This work was funded by the National Research, Development and Innovation Office (OTKA) K 112554 project. J. Halász is grateful for receiving the János Bolyai Research Scholarship of the Hungarian Academy of Sciences.

N. Makovics-Zsohár thanks the support of the ÚNKP-16-3-I, New National Excellence Program of the Ministry of Human Capacities.

${ }^{1}$ Corresponding authors. E-mail: halasz.julia@kertk. szie.hu or genetics.prunus@gmail.com. fresh consumption, in spirit production, jam making, drying, cooking, and baking products (Neumüller, 2011; Saridas et al., 2016). Plums belong to the genus Prunus of the family Rosaceae. The wild type of the species is still unknown; however, several hypotheses were created about its origin. The hexaploid $(2 n=6 x=48) P$. domestica is proved to be a relatively young species (Das et al., 2011). It is most likely that the extant European lineages Prunus spinosa, Prunus cerasifera, and $P$. domestica descended from an ancestor that migrated from eastern Asia (Chin et al., 2014).

Traditional cultivars were mainly obtained as selections of primitive forms and hence their origin is unknown. Modern cultivars arose from breeding programs started in the second half of the 20th century, and double crossing, pyramidic crossing, mutagenesis, and several laboratory assays were used in such programs compared with traditional breeding (Hartman and Neumüller, 2009). The main purposes of modern plum breeding are climatic adaptation, precocity, high and regular yield, extension of ripening time, high fruit quality, and abiotic and biotic resistance. The genetic variability of accessions was initially based on assessing morphological traits. European plum is a less-investigated species in the Prunoideae subfamily because of the complex structure of its genome (Neumüller, 2011). In addition, genetic linkage maps or the whole genome sequence of the species is not available yet. Molecular markers developed from Prunus species offer a reliable tool to study and understand genome evolution and structure, the estimation of genetic diversity, the determination of genetic relationship, and the identification of cultivars (Gharbi et al., 2014; Wünsch, 2009). Analysis of genetic relationships and diversity in cultivated species is a key point in crop improvement because it supports the selection of parental genotypes and contributes to the planning of offspring genome; hence, it can be an invaluable tool in breeders' hands (Benjak et al., 2005; Sorkheh and Khaleghi, 2016; Yazici and Sahin, 2016).

The first reports on cultivar identification of $P$. domestica were based on randomly amplified polymorphic DNA analysis (Gregor et al., 1994). Microsatellites or SSRs are highly informative, reproducible, multiallelic, abundant, locus-specific, and codominant markers. Based on these features, they present a useful tool for plant molecular genetic studies, such as genetic mapping, population genetics, marker-assisted selection, or fingerprinting (Wünsch, 2009). Conservation of Prunus SSR loci ranged between $57 \%$ and $100 \%$, which means that the same primer set could be used in case of different species within the genus (Mnejja et al., 2004).

The parentage of three European plum cultivars ('Cacanska najbolja', 'Cacanska rana', and 'Cacanska lepotica') was reconstructed using nuclear and chloroplastic microsatellite analyses (Decroocq et al., 2004). SSR markers also allowed identifying different clones of 'Reine Claude Verte' (Gharbi et al., 2014). In addition, efforts were devoted to study germplasm collections in different countries using SSR markers (Horvath et al., 2011; Kazija et al., 2014; Sehic et al., 2015). SSR analysis of traditional Turkish plums collected in east Anatolia revealed high genetic diversity (Öz et al., 2013).

Some plum species are native to Hungary (Rapaics, 1940). Plums in Hungary are highly variable because of the spontaneous hybridization among different species. Furthermore, some of the local genotypes have been propagated by seeds over centuries (Surányi, 1998) which contributed to the high diversity available within the country. These genotypes are well adapted to the local climatic conditions, they show elevated resistance to pests and diseases, and they are also characterized by special organoleptic qualities (Sehic 
et al., 2015). Maintenance of landraces and traditional cultivars may help in these serving as valuable gene resources.

Degree of genetic diversity is a fundamental parameter in both conservation biology and breeding programs. Because there is no exact information on the genetic background of Hungarian plums, our objective was to fingerprint 55 European plums using SSR markers to estimate the polymorphism level, determine allelic variation among Hungarian landraces, and comparing the results with those of the economically important, internationally widespread cultivars.

\section{Materials and Methods}

Plant material. A total of 55 plum genotypes $[P$. domestica L., Prunus italica Borkh., Prunus insititia L., Prunus cerasifera Ehrh., Prunus syriaca (Borkh.) Karp., Prunus cocomilia Ten., and a Prunus besseyi Bail. $\times$ Prunus salicina Lindl. hybrid] originated in different geographical regions were evaluated in the experiments. The Hungarian and foreign plum cultivars are kept in the germplasm collection of the Szent István University, Faculty of Horticultural Science in Budapest (Soroksár) and National Agricultural Research and Innovation Center, Fruitculture Research Institute, Research Station of Cegléd. The samples include 19 modern foreign cultivars, 13 traditional cultivars, 20 landrace cultivars, and three rootstock cultivars (Table 1). Taxonomic classification and origin of the less-known cultivars are given

Table 1. Taxonomic classification, origin, and cultivar status of the analyzed plum accessions and their classification into reconstructed populations (RP) defined by STRUCTURE (Pritchard et al., 2000).

\begin{tabular}{|c|c|c|c|c|c|}
\hline Accession & Presumed species & Pedigree & Country of origin & Cultivar status ${ }^{z}$ & $\operatorname{RP}^{\mathrm{y}}(K=3)$ \\
\hline Althann's Gauge & Prunus italica & Unknown & Czech Republic & $\mathrm{T}$ & 1 \\
\hline Beregi datolya & Prunus domestica & Unknown & Hungary & $\mathrm{L}$ & 3 \\
\hline Besztercei 105-58 & P. domestica & Clone of Besztercei & Hungary & $\mathrm{T}$ & 2 \\
\hline Besztercei Bb. 398 & P. domestica & Clone of Besztercei & Hungary & $\mathrm{T}$ & 2 \\
\hline Besztercei Bt. 2 & P. domestica & Clone of Besztercei & Hungary & $\mathrm{T}$ & 2 \\
\hline Besztercei Nm.122. & P. domestica & Clone of Besztercei & Hungary & $\mathrm{T}$ & 2 \\
\hline Besztercei Nm.150. & P. domestica & Clone of Besztercei & Hungary & $\mathrm{T}$ & 2 \\
\hline Besztercei szilva & P. domestica & Selection of primitive form; ANP $^{x}$ & Hungary & $\mathrm{T}$ & 2 \\
\hline Bluefre & P. domestica & Stanley $\times$ President & USA & M & 1 \\
\hline Bódi szilva 1. & Prunus insititia & Selection of primitive form; $\mathrm{ANP}^{\mathrm{x}}$ & Hungary & $\mathrm{L}$ & 3 \\
\hline Bódi szilva 2. & P. insititia & Selection of primitive form; $\mathrm{ANP}^{\mathrm{x}}$ & Hungary & $\mathrm{L}$ & 3 \\
\hline Bühler Frühzwetschge & P. domestica & Unknown & Germany & $\mathrm{T}$ & 2 \\
\hline C. 174 myrobalan & Prunus cerasifera & Selection of primitive form; $\mathrm{KNP}^{\mathrm{x}}$ & Hungary & $\mathrm{R}$ & 1 \\
\hline C. 679 myrobalan & P. cerasifera & Selection of primitive form; $\mathrm{KNP}^{\mathrm{x}}$ & Hungary & $\mathrm{R}$ & 1 \\
\hline Cacanska lepotica $^{\mathrm{w}}$ & P. domestica & Wangenheimer $\times$ Besztercei & Serbia & M & 1 \\
\hline Duránci & P. domestica & Selection of primitive form; ANP $^{x}$ & Hungary & $\mathrm{L}$ & 2 \\
\hline Durkó & P. domestica & Selection of primitive form; $\mathrm{ANP}^{\mathrm{x}}$ & Hungary & $\mathrm{L}$ & 2 \\
\hline Elein érő & P. domestica & Selection of primitive form; $\mathrm{ANP}^{\mathrm{x}}$ & Hungary & $\mathrm{L}$ & 3 \\
\hline Elena & P. domestica & Fellenberg $\times$ Stanley & Germany & M & 1 \\
\hline Empress & P. domestica & Unknown & Italy & M & 1 \\
\hline Fehérszilva 1. & P. domestica & Selection of primitive form; ANP $^{x}$ & Hungary & $\mathrm{L}$ & 3 \\
\hline Fehérszilva 2. & P. domestica & Selection of primitive form; $\mathrm{ANP}^{\mathrm{x}}$ & Hungary & $\mathrm{L}$ & 3 \\
\hline Fehérszilva 3. & P. domestica & Selection of primitive form; $\mathrm{ANP}^{\mathrm{x}}$ & Hungary & $\mathrm{L}$ & 3 \\
\hline Fehérszilva 4. & P. domestica & Selection of primitive forms; $\mathrm{ANP}^{\mathrm{x}}$ & Hungary & $\mathrm{L}$ & 3 \\
\hline French Orange & P. domestica & Unknown & France & $\mathrm{T}$ & 3 \\
\hline Gömöri nyakas 1. & P. domestica & Unknown; ANP ${ }^{x}$ & Hungary & $\mathrm{L}$ & 2 \\
\hline Gömöri nyakas 2. & P. domestica & Unknown; ANP ${ }^{x}$ & Hungary & $\mathrm{L}$ & 2 \\
\hline Green Gauge & P. italica & Unknown & Italy & $\mathrm{T}$ & 3 \\
\hline Haganta & P. domestica & Cacanska najbolja $\times$ Valor & Germany & M & 1 \\
\hline Hanita $^{w}$ & P. domestica & President $\times$ Auerbacher & Germany & M & 1 \\
\hline Haroma & P. domestica & $($ Ortenauer $\times$ Stanley 34$) \times$ Hanita & Germany & M & 1 \\
\hline Hollandi szilva C. 940 & P. italica & Unknown & Hungary & M & 1 \\
\hline Jojo $^{\mathrm{w}}$ & P. domestica & Ortenauer $\times$ Stanley & Germany & M & 1 \\
\hline Katinka & P. domestica & Ortenauer $\times$ Ruth Gerstetter & Germany & M & 1 \\
\hline Kecskeméti 101 & P. domestica & Unknown & Hungary & $\mathrm{L}$ & 2 \\
\hline Kökényszilva CT 93 & P. insititia & Selection of primitive form; $\mathrm{KNP}^{\mathrm{x}}$ & Hungary & $\mathrm{R}$ & 3 \\
\hline Lengyel & P. domestica & Progeny of Besztercei & Hungary & M & 1 \\
\hline Lószemü szilva & P. domestica & Selection of primitive form; ANP $^{x}$ & Hungary & $\mathrm{L}$ & 1 \\
\hline Mirabelle de Nancy & Prunus syriaca & Unknown & France & $\mathrm{T}$ & 1 \\
\hline Nemtudom P3 & P. insititia & Selection of primitive form; $\mathrm{SzB}^{\mathrm{x}}$ & Hungary & $\mathrm{L}$ & 3 \\
\hline Oka & Prunus besseyi $\times$ Prunus salicina & Unknown & USA & M & 1 \\
\hline Páczelt szilvája & P. domestica & Unknown & Hungary & $\mathrm{L}$ & 2 \\
\hline Presenta & P. domestica & President $\times$ Ortenauer & Germany & M & 1 \\
\hline President $^{\mathrm{w}}$ & P. domestica & Unknown & Great Britain & M & 1 \\
\hline Sermina & P. cocomilia & Unknown & unclear & M & 1 \\
\hline Sivákló & P. domestica & Selection of primitive forms, $\mathrm{ANP}^{\mathrm{x}}$ & Hungary & $\mathrm{L}$ & 3 \\
\hline Stanley $^{\mathrm{w}}$ & P. domestica & Agen $\times$ Grand Duke & USA & M & 1 \\
\hline Topend Plus & P. domestica & Cacanska najbolja $\times$ Valor & Germany & M & 1 \\
\hline Topfive & P. domestica & Cacanska najbolja $\times$ Auerbacher & Germany & M & 1 \\
\hline Tophit & P. domestica & Cacanska najbolja $\times$ President & Germany & M & 1 \\
\hline Tuleu gras & P. domestica & Unknown & Romania & $\mathrm{T}$ & 2 \\
\hline Victoria & P. domestica & Unknown & Great Britain & $\mathrm{T}$ & 1 \\
\hline Vörös szilva 1. & P. domestica & Selection of primitive forms, $\mathrm{ANP}^{\mathrm{x}}$ & Hungary & $\mathrm{L}$ & 3 \\
\hline Vörös szilva 2. & P. domestica & Selection of primitive forms, $\mathrm{ANP}^{\mathrm{x}}$ & Hungary & $\mathrm{L}$ & 3 \\
\hline Vörös szilva 3. & P. domestica & Selection of primitive forms, $\mathrm{ANP}^{\mathrm{x}}$ & Hungary & $\mathrm{L}$ & 3 \\
\hline
\end{tabular}

${ }^{\mathrm{z}}$ Cultivar status: $\mathrm{M}=$ modern/improved cultivar; $\mathrm{T}=$ traditional/heirloom cultivar (introduced commercially before the 20 th century); $\mathrm{L}=$ landrace/autochthonous cultivar; $\mathrm{R}=$ used as rootstock.

${ }^{y}$ RP: 1 (blue); 2 (red); 3 (green).

${ }^{\mathrm{x}}$ ANP = Aggtelek National Park; KNP = Kiskunság National Park; SzB = Szatmár-Bereg Landscape Protection Area.

${ }^{\mathrm{w}}$ International reference cultivar. 
based on previous reports (Gough, 2011; Surányi, 1998, 2006b, 2013; Surányi and Erdős, 2004; Tóth and Surányi, 1980). In consideration of fruit and stone morphology, the original classification of 'Lószemü szilva' (P. italica) provided by Rapaics (1940) was revised to $P$. domestica.

$D N A$ extraction and polymerase chain reaction $(P C R)$ conditions. Genomic DNA was extracted from fully expanded young leaves using a DNeasy Plant Mini Kit (Qiagen, Hilden, Germany). DNA concentrations and purification parameters were measured using a NanoDrop ND-1000 spectrophotometer (Bio-Science, Budapest, Hungary). A set of seven SSR primer pairs was selected on the basis of previous reports on different Prunus species, covering different linkage groups (Table 2). The forward primers were labeled with 6-FAM fluorescent dye for detection in a capillary genetic analyzer. PCRs were carried out in a PTC 200 thermocycler (MJ Research, Budapest, Hungary) using the program described for the primers. About 20-80 ng of genomic DNA was used for PCR amplification in a $25-\mu \mathrm{L}$ reaction volume containing 10× DreamTaq Green buffer (Fermentas, Szeged, Hungary) as well as $\mathrm{KCl}$ and $\left(\mathrm{NH}_{4}\right)_{2} \mathrm{SO}_{4}$ at a ratio optimized for robust performance of DreamTaq DNA polymerase in PCR with final concentrations of $4.5 \mathrm{~mm}$ of $\mathrm{MgCl}_{2}$, $0.2 \mathrm{~mm}$ of dNTPs, $0.2 \mu \mathrm{m}$ of the adequate primers, and $0.75 \mathrm{U}$ of DreamTaq DNA polymerase (Fermentas).

Electrophoresis of PCR products and allele sizing. To control PCR and determine the approximate sizes of the alleles amplified, $4 \mu \mathrm{L}$ of the PCR products were separated by electrophoresis in 1.2\% Tris-acetate-EDTA agarose gels for $2 \mathrm{~h}$ at $100 \mathrm{~V}$ and DNA bands were visualized by ethidium bromide staining. Fragment lengths were estimated by comparison with a 1-kb DNA ladder (Promega, Madison, WI). To determine the exact size of the fragments, the fluorescently labeled products were run on an automated sequencer ABI Prism 3100 Genetic Analyzer (Applied Biosystems, Budapest, Hungary).

Data analysis. For determination of fragment sizes (genotyping), GENOTYPER 3.7 software and the GS500 LIZ size standard (Applied Biosystems) were used. For phylogenetic analysis, each detected allele from SSR genotyping was scored as present (1) or absent (0). The neighbor-joining algorithm was used to construct a dendrogram based on Jaccard's index using the software PAST 2.17c (Hammer et al., 2001). Numbers on major branches represent bootstrap supports from 2000 replicates. PCA was also carried out using PAST software.

To further analyze the genetic composition of plum accessions, a Bayesian approach was used to estimate the number of clusters with STRUCTURE 2.3.4. software (Pritchard et al., 2000). Because the analyzed genotypes were derived from different breeding programs and natural hybridization, the "admixture ancestry" and the "correlated allele frequency" parameters were used. For individuals with less than six allelic variants per locus, absent allele(s) were assigned as missing data (-9). $K$ was set from one to 15 , each run was replicated 10 times, with the burn-in period of 100,000 followed by 100,000 Markov Chain Monte Carlo repetitions. Estimation of the best $K$ value was conducted with STRUCTURE Harvester (Earl and Von Holdt, 2012) following the method of Evanno et al. (2005). POLYSAT (Clark and Jasieniuk, 2011) was used to estimate pairwise $F_{\text {st }}$ values according to Nei (1973).

\section{Results and Discussion}

In 55 plum accessions, amplification of genomic DNA was successful in each of the seven SSR loci developed from different Prunus species (peach, almond, and plum). Altogether, the primer pairs produced a total of 135 alleles ranging from six to 27 alleles per locus. A wide range of fragment length was detected among the accessions, from 108 to $268 \mathrm{bp}$. Magnitude in the length of the repeat can reach more than 70 bp (CPDCT044) (Table 2). All loci showed a maximum of six alleles per genotype in accordance with the hexaploid level of the species. Sehic et al. (2015) stated that the scoring process of SSR alleles is much more complicated in the case of polyploid species than it is with diploids, which can affect the reproducibility of the analyses. SSR markers are codominant; however, it is difficult to determine the number of loci and copies of an allele in a polyploid genome without progeny analysis (Barac et al., 2014).

The mean value found was 19.3 alleles per locus, which is similar to other studies on European plum. Sehic et al. (2015) found 22.7 alleles per locus in 76 plum genotypes, Kazija et al. (2014) reported 18.7 alleles per locus on 62 plum accessions, whereas Xuan et al. (2011) registered 20 alleles per locus in 45 cultivars. The seven SSR markers in the present study displayed relatively high polymorphism levels: CPDCT044 had the largest number of alleles (27), whereas ВРPCT037 amplified the smallest number of alleles (6). Our results are attributed to the great genetic diversity of tested accessions which can be a consequence of the complex polyploid genome structure. All genotypes were clearly distinguished with the seven SSRs used in this study, indicating that microsatellite analysis is an appropriate tool for the identification and fingerprinting of plum cultivars. Merkouropoulos et al. (2017) also used a total of seven microsatellite markers that were enough to discriminate 54 plum cultivars.

The genetic relationships among plum cultivars and genotypes of different origin were depicted using neighbor-joining cluster analysis (Fig. 1). The 55 plum cultivars were classified into three main groups of different sizes. It is interesting that these cultivars represent seven different plum species with various ploidy levels $(P$. domestica, $P$. italica, $P$. insititia, $P$. cerasifera, $P$. syriaca, $P$. besseyi $\times P$. salicina, and $P$. cocomilia), but samples belonging to the same species did not group together. Because all species are able to hybridize, intermediate forms may exist between each of the species (Neumüller, 2011), resulting in the absence of a strong discriminating line around the genotypes supposed to represent different species. The only exception to the mixed arrangement was the out-group formed by the diploid species 'Oka' and two myrobalan accessions. Most international modern cultivars grouped together, whereas Hungarian traditional cultivars and landraces appear to be more diversified with some distantly related accessions (e.g., 'Besztercei' clones and 'Beregi datolya'). The foreign cultivars positioned distantly from the Hungarian accessions in the dendrogram similarly to the position of 'Stanley' among east Anatolian traditional plums (Öz et al., 2013).

STRUCTURE analysis was carried out to determine the genetic constitution of different groups. On the basis of molecular data, our results from Bayesian clustering analysis confirmed the groupings we detected in the neighbor-joining dendrogram (Fig. 1). The most likely value of $K$ was 3 , indicating three genetically distinct reconstructed populations (RPs) within the studied genotypes. The first $\mathrm{RP}$ (RP1, blue) is the biggest group with 25 genotypes. It contains all foreign, modern, and traditional polyploid cultivars with two diploid $P$. cerasifera rootstock accessions. Hungarian landraces and Hungarian traditional cultivars formed two different groups, because the second RP (RP2, red) contains 16

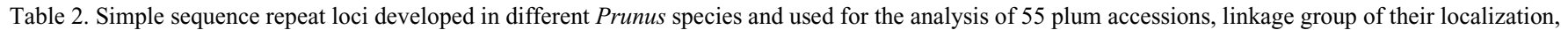
annealing temperature, number of amplified alleles, and size range of fragments (bp).

\begin{tabular}{|c|c|c|c|c|c|c|}
\hline Locus name & Linkage group & Species & Reference & $\mathrm{Ta}\left({ }^{\circ} \mathrm{C}\right)$ & Number of alleles & Range size (bp) \\
\hline ВРPCТ025 & $\mathrm{G} 6$ & Peach & Dirlewanger et al. (2002) & 57 & 21 & $150-212$ \\
\hline ВРРСТ007 & G3 & Peach & Dirlewanger et al. (2002) & 57 & 17 & $122-154$ \\
\hline ВРРСТ037 & G5 & Peach & Dirlewanger et al. (2002) & 57 & 5 & $108-130$ \\
\hline ВРРСТ039 & G3 & Peach & Dirlewanger et al. (2002) & 55 & 17 & $114-156$ \\
\hline ВРРСТ040 & G4 & Peach & Dirlewanger et al. (2002) & 56 & 14 & $118-152$ \\
\hline CPSCT021 & G2 & Japanese plum & Mnejja et al. (2004) & 56 & 23 & $120-176$ \\
\hline СРDCT044 & $\mathrm{G} 2$ & Almond & Mnejja et al. (2005) & 58 & 26 & $198-268$ \\
\hline
\end{tabular}




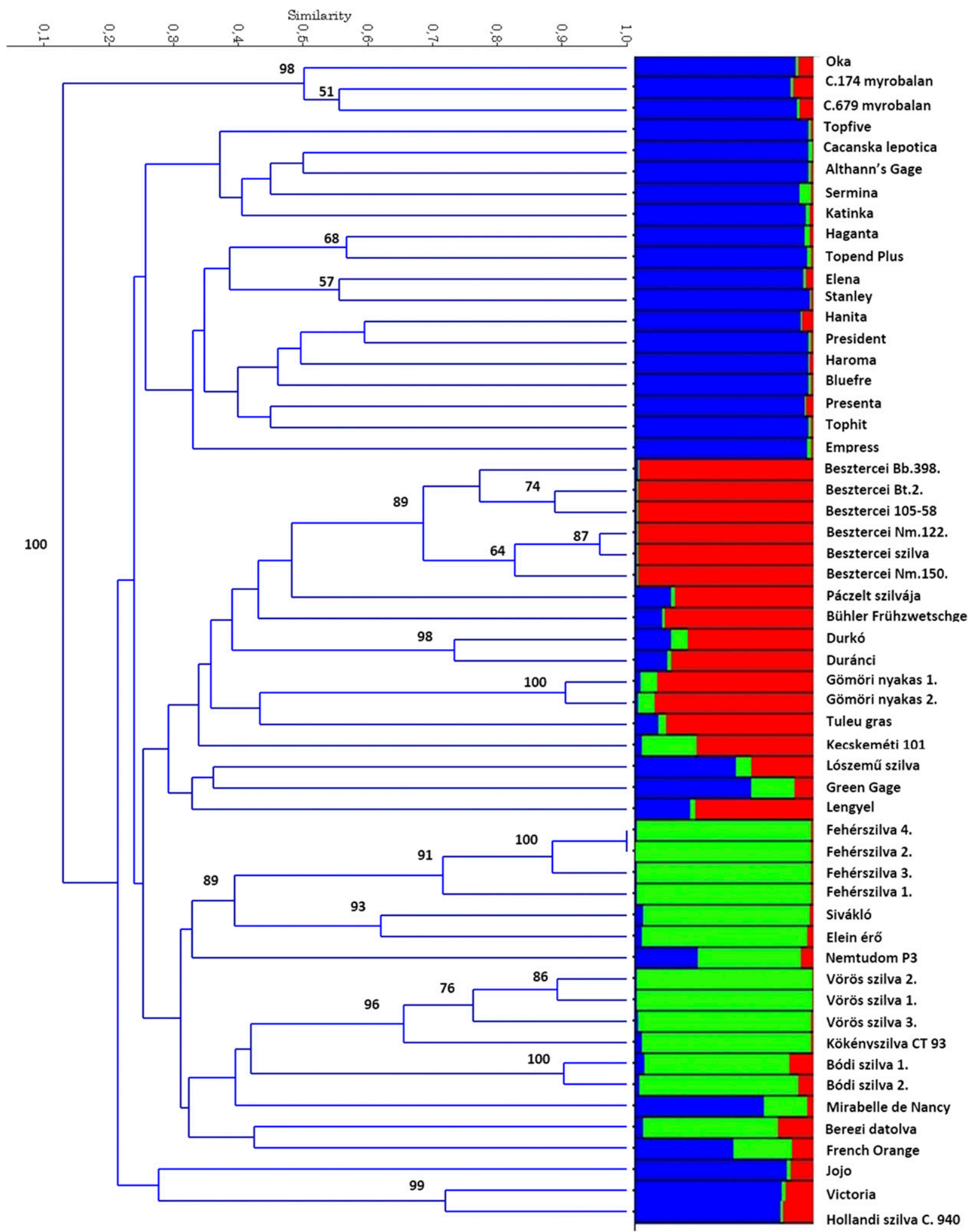

Fig. 1. Neighbor-joining dendrogram of Jaccard's indices and genetic structure of 55 plum cultivars performed with seven simple sequence repeat markers. The genotyping results were used to classify the cultivars into subpopulations, only confident branches with bootstrap values $\geq 50$ were assigned. Genetic structure was revealed by STRUCTURE program with $K=3$ as found by simulation and $\Delta K$ likelihood method. The division of $Q$-value bar plot into three reconstructed populations corresponds to the three major significant clusters in the dendrogram.

and the third RP (RP3, green) includes other 14 Hungarian accessions. It is remarkable that none of the modern cultivars was placed within these two groups, and only two foreign traditional cultivars clustered to both the RP2 ('Tuleu gras' and 'Bühler Frühzwetschge') and RP3 groups ('Mirabelle de Nancy' and 'French Orange'). Differentiation, estimated as the $F_{\text {st }}$ value, among the three groups of plum accessions was the highest (0.0431) in the case of RP1 including foreign cultivars. Lower genetic differentiation characterized the two other RPs (RP2 $F_{\text {st }}=0.0234$ and RP3 $F_{\text {st }}=0.0294$ ) containing the Hungarian accessions. This tendency highlights the marked genetic differences between the modern, foreign, and traditional Hungarian plum cultivars. 
Parent-offspring relationships among some cultivars ('Bluefre', 'Stanley', 'President', 'Hanita', 'Haroma', and 'Presenta') are shown in Table 1. Such cultivars clustered closely on the dendrogram according to their pedigree. Accessions within the Hungarian landrace cultivar groups ('Besztercei', 'Fehérszilva', 'Vörös szilva', 'Bódi szilva', and 'Gömöri nyakas') grouped together with strong bootstrap support $(89 \%$ to $100 \%)$. From several accessions known under the same name, only Fehérszilva 4 and Fehérszilva 2 proved to be identical. Other genotypes labeled by a common name were found to be different from each other in some of the assayed loci. Using seven SSRs, differences occurred among 'Vörös szilva', 'Gömöri nyakas', and 'Bódi szilva' accessions collected in different geographical locations. Traditionally, landraces showing similar morphological characters were labeled with the same name by village people, and they have been propagating those landraces by seeds for decades, which resulted in a certain level of genetic variations within specific landrace cultivar groups (Surányi, 2006a, 2013; Tóth and Szani, 2004). 'Besztercei' plums were considered the first and most important landrace cultivar in Hungary (Rapaics, 1940). Because of the previously described reasons, genetic variations were described among 'Besztercei' plum trees and several forms were selected to combat genetic erosion experienced after some time in cultivation. First reports on the selected clones reflected differences in ripening time, size of fruits, and productivity (Harsányi, 1997), whereas later productivity was confirmed to be the only characteristic significantly improved by this strategy (Surányi, 2006a). Analysis of 50
'Besztercei' clones from a germplasm collection in Cegléd revealed diversity in 10 morphological traits and Plum pox virus (PPV) resistance (Surányi, 2006b). Each of the six 'Besztercei' plums used in this study showed a unique SSR fingerprint different from others, and the clones grouped together in two small subgroups, both containing three accessions. It indicates that improving this cultivar by clonal selection is a valid approach with inherent perspectives that might be exploited in future breeding. Our results proved the role and potential of markerassisted selection methods in plum breeding.

PCA (Fig. 2) confirmed the information provided by the dendrogram and also supplied further details. The first two principal axes accounted for $12.03 \%$ and $10.20 \%$ of the total variation, respectively, together explaining $22.23 \%$ of the total variability. In the PCA scatter plot, clear separation occurred among 'Fehérszilva' accessions. Two hypotheses have been put forward for the origin of 'Fehérszilva': 1) 'Fehérszilva' is a mutant form of 'Vörös szilva' (Surányi, 2013) and 2) 'Fehérszilva' was developed from 'Besztercei' and it is also known as 'Fehér Besztercei' (Nagy, 1980). 'Fehérszilva' accessions were closer to 'Vörös szilva' genotypes and hence our SSR analysis seems to support the first theory.

The substantial dispersion of Hungarian traditional cultivars and landraces suggests a high level of genetic diversity present within the analyzed germplasm. Indeed, unique alleles were registered among the landraces in five SSR loci. It would be important to use this plant material in breeding programs to increase genetic variability that has been narrowed over the last decades because of the frequent application of some popular foreign cultivars. 'Gömöri nyakas', 'Nemtudom P3', 'Fehérszilva', 'Beregi datolya', and 'Vörös szilva' proved to be PPV tolerant in field experiments, which further demonstrates their value in future breeding or cultivation. In addition, 'Bódi szilva' and 'Nemtudom szilva' also proved to show elevated abiotic stress resistance (Pethö, 2011; Surányi, 2013). Local plum cultivars and primitive landraces were reported to be perspective donors of resistance to frost and drought (Paunovic, 1988).

Moreover, some of the Hungarian plums analyzed are useful as rich genetic resources to improve fruit quality and increase the nutritional content and health benefits of future cultivars. Large differences have been reported between the Hungarian landraces and the modern foreign cultivars with regard to carbohydrate profiles. The fruits of 'Vörös szilva' and 'Lószemü szilva' are rich in sugar alcohol (sorbitol), whereas 'Bódi szilva', 'Vörös szilva', and 'Besztercei szilva' produce monosaccharide-dominated fruits (Tóth, 2013). Tóth (1957) detected 22\% total sugar in the fruit juice of 'Duránci'.

The laxative effect of plum and plum juice was attributed to the presence of phenolics (mainly chlorogenic and neochlorogenic acids) and sorbitol coupled with its high fiber content in fruits (Stacewicz-Sapuntzakis et al., 2001). This composition might also be the explanation why plums that are a good source of energy in the form of simple sugars do not mediate a rapid rise in blood sugar concentration. In addition, phenolic compounds and microelements accumulated in plums may serve as preventive agents against severe chronic diseases including cardiovascular

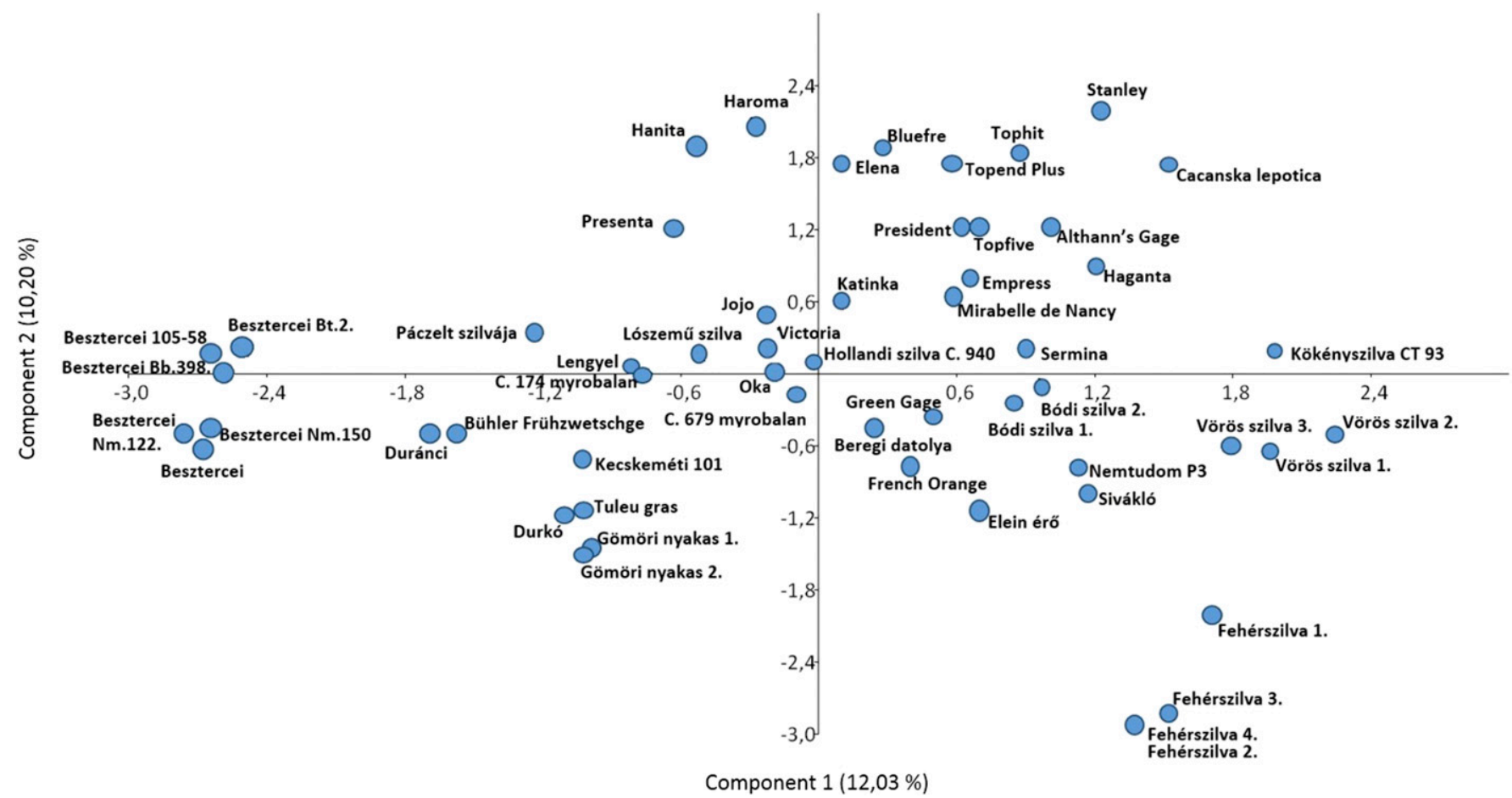

Fig. 2. Distribution of 55 plum cultivars on the two first principal component analysis axes determined from simple sequence repeat genotyping. 
disease, cancer, and osteoporosis (Igwe and Charlton, 2016).

'Pożegača' (syn. 'Besztercei szilva') had the 13th highest total phenolics content among 178 cultivars of plum (Sahamishirazi et al., 2017), indicating that some genotypes with outstanding fruit composition might be found among the genetically diverse local landrace cultivars, as it was found in the Hungarian sour cherry breeding program (Papp et al., 2010). Our data provided valuable information on local European plum germplasm in Hungary by detecting considerable genetic diversity that might be exploited in future breeding programs. Molecular marker strategies will undoubtedly contribute to reinforced breeding activity in plum by helping in the conservation, valorization, and the most efficient use of landrace cultivars to combine their outstanding fruit properties with other beneficial characteristics (e.g., disease resistance) provided by foreign cultivars.

\section{Literature Cited}

Barac, G., V. Ognjanov, D. Obreht, M. Ljubojevic, D. Bosnjakovic, I. Pejic, and K. Gasic. 2014. Genotypic and phenotypic diversity of cherry species collected in Serbia. Plant Mol. Biol. Rpt. 32:92-108.

Benjak, A., S. Ercisli, A. Vokurka, E. Maletic, and I. Pejic. 2005. Genetic relationships among grapevine cultivars native to Croatia, Greece and Turkey. Vitis 44:73-77.

Chin, S.W., J. Shaw, R. Haberle, J. Wen, and D. Potter. 2014. Diversification of almonds, peaches, plums and cherries-Molecular systematics and biogeographic history of Prunus (Rosaceae). Mol. Phylogenet. Evol. 76:34-48.

Clark, L.V. and M. Jasieniuk. 2011. POLYSAT: An $\mathrm{R}$ package for polyploid microsatellite analysis. Mol. Ecol. Resour. 11:562-566.

Das, B., N. Ahmed, and P. Singh. 2011. Prunus diversity- early and present development: A review. Intl. J. Biodivers. Conserv. 3:721-734.

Decroocq, V., L.S. Hagen, M-G. Favé, J-P. Eyquard, and A. Pierronnet. 2004. Microsatellite markers in the hexaploid Prunus domestica species and parentage lineage of three European plum cultivars using nuclear and chloroplast simple-sequence repeats. Mol. Breed. 13:135-142.

Dirlewanger, E., P. Cosson, M. Tavaud, M. Aranzana, C. Poizat, A. Zanetto, P. Arús, and F. Laigret. 2002. Development of microsatellite markers is peach [Prunus persica (L.) Batsch] and their use in genetic diversity analysis in peach and sweet cherry (Prunus avium L.). Theor. Appl. Genet. 105:127-138.

Earl, D.A. and B.M. Von Holdt. 2012. STRUCTURE HARVESTER: A website and program for visualizing STRUCTURE output and implementing the Evanno method. Conserv. Genet. Resour. 4:359-361.

Evanno, G., S. Regnault, and J. Goudet. 2005. Detecting the number of clusters of individuals using the software structure: A simulation study. Mol. Ecol. 14:2611-2620.

Faust, M. and D. Surányi. 1999. Origin and dissemination of plums. Hort. Rev. 23:179232.

Gharbi, O., A. Wünsch, and J. Rodrigo. 2014. Characterization of accessions of 'Reine Claude Verte' plum using Prunus SRR and phenotypic traits. Sci. Hort. 169:57-65.
Gough, R.E. 2011. Growing minor stone fruit in Montana. Montana State University Extension, Bozeman, MT.

Gregor, D., W. Hartmann, and R. Stosser. 1994. Cultivar identification in Prunus domestica using random amplified polymorphic DNA markers. Acta Hort. 359:33-40.

Hammer, Ř., D.A.T. Harper, and P.D. Ryan. 2001 PAST: Paleontological statistics software package for education and data analysis. Palaeontol. Electron. 4:910 Aug. 2016. <http:// palaeo-electronica.org/2001_1/past/issue1_01. htm>.

Harsányi, J. 1997. Plums, p. 184-224. In: P Tomcsányi (ed.). Fruit varieties, practical pomology. Mezőgazdasági Kiadó, Budapest, Hungary (in Hungarian).

Hartmann, W. and M. Neumüller. 2009. Plum breeding, p. 161-231. In: P.M. Priyadarshan and S. Mohan Jain (eds.). Breeding plantation tree crops: Temperate species. Springer, New York, NY.

Horvath, A., E. Balsemin, J.C. Barbot, H. Christmann, G. Manzano, P. Reynet, F. Laigret, and S. Mariette. 2011. Phenotypic variability and genetic structure in plum (Prunus domestica L.), cherry plum (P. cerasifera Ehrh.) and sloe (P. spinosa L.). Sci. Hort. 129:283-293.

Igwe, E.O. and K.E. Charlton. 2016. A systematic review on the health effects of plums (Prunus domestica and Prunus salicina). Phytother. Res. 30:701-731.

Kazija, D.H., T. Jelačić, P. Vujević, B. Milinović, D. Čiček, A. Biško, and D. Nikolić. 2014. Plum germplasm in Croatia and neighboring countries assessed by microsatellites and DUS descriptors. Tree Genet. Genomes 10:761778.

Merkouropoulos, G., I. Ganopoulos, A. Tsaftaris, I. Papadopoulos, and P. Drogoudi. 2017. Combination of high resolution melting (HRM) analysis and SSR molecular markers speeds up plum genotyping: Case study genotyping the Greek plum Gene Bank collection. Plant Genet. Resour. 15:366-375.

Mnejja, M., J. Garcia, W. Howad, M.L. Badenes, and P. Arús. 2004. Simple-sequence repeat (SSR) markers of Japanese plum (Prunus salicina Lindl.) are highly polymorphic and transferable to peach and almond. Mol. Ecol. Notes 4:163-166.

Mnejja, M., J. Garcias-Mas, W. Howad, and P. Arús. 2005. Development and transportability across Prunus species of 42 polymorphic almond microsatellites. Mol. Eco. Notes. 53:531-535

Nagy, P. 1980. Plum clonal rootstocks of apricot. Szőlö- és Gyümölcstermesztés 4:37-45 (in Hungarian).

Nei, M. 1973. Analysis of gene diversity in subdivided populations. Proc. Natl. Acad. Sci. USA 70:3321-3323.

Neumüller, M. 2011. Fundamental and applied aspects of plum (Prunus domestica) breeding. Fruit. Veg. Cereal Sci. Biotech. 5:139-156.

Öz, M.H., H. Vurgun, M. Bakir, Í. Büyük, C. Yüksel, H.M. Ünlü, K. Çukadar, B. Karadoğan, Ö. Köse, and A. Ergül. 2013. Molecular analysis of East Anatolian traditional plum and cherry accessions using SSR markers. Genet. Mol. Res. 12:5310-5320.

Papp, N., B. Szilvássy, L. Abrankó, T. Szabó, P. Pfeiffer, Z. Szabó, J. Nyéki, S. Ercisli, É. Stefanovits-Bányai, and A. Hegedüs. 2010. Main quality attributes and antioxidants in Hungarian sour cherries: Identification of genotypes with enhanced functional properties. Intl. J. Food Sci. Technol. 45:395-402.
Paunovic, S.A. 1988. Plum genotypes and their improvement in Yugoslavia. Fruit Var. J. 42:143-151.

Pethő, F. 2011. Monography of Nemtudom plum. Újfehértói GyKSz Nonprofit Közhasznú Kft., Újfehértó (in Hungarian).

Pritchard, J.K., M. Stephens, and P. Donelly. 2000. Inference of population structure using multilocus genotype data. Genetics 155:945-959.

Rapaics, R. 1940. Fruits in Hungary. Királyi Magyar Természettudományi Társulat, Budapest, Hungary (in Hungarian).

Sahamishirazi, S., J. Moehring, W. Claupein, and S. Graeff-Hoenninger. 2017. Quality assessment of 178 cultivars of plum regarding phenolic, anthocyanin and sugar content. Food Chem. 214:694-701.

Saridas, M.A., N.E. Kafkas, M. Zarifikhosroshahi, O. Bozhaydar, and S.P. Kargi. 2016. Quality traits of green plums (Prunus cerasifera Ehrh.) at different maturity stages. Turk. J. Agr. For. 40:655-663.

Sehic, J., H. Nybom, S.H. Hjeltnes, and F. Gaši. 2015. Genetic diversity and structure of Nordic plum germplasm preserved ex situ and onfarm. Sci. Hort. 190:195-202.

Sorkheh, K. and E. Khaleghi. 2016. Molecular characterization of genetic variability and structure of olive (Olea europaea L.) germplasm collection analyzed by agromorphological traits and microsatellite markers. Turk. J. Agr. For. 40:583-596.

Stacewicz-Sapuntzakis, M., P.E. Bowen, E.A. Hussain, B.I. Damayanti-Wood, and N.R. Farnsworth. 2001. Chemical composition and potential health effects of prunes: A functional food? Crit. Rev. Food Sci. Nutr. 41:251-286.

Surányi, D. 1998. Wild plums in Hungary and its improvement. Acta Hort. 478:217-224.

Surányi, D. 2006a. Plums. Mezőgazda Kiadó, Budapest, Hungary (in Hungarian).

Surányi, D. 2006b. Our national and cultural affairs: A historical-pomological study of Besztercei plum. Tájökol. Lapok 4:65-77. (in Hungarian).

Surányi, D. 2013. Plum cultivars, p. 377-393. In: M. Soltész (ed.). Hungarian fruit cultivars. Mezőgazda Kiadó, Budapest, Hungary (in Hungarian).

Surányi, D. and Z. Erdős. 2004. Possibilities and difficulties of cultivar introduction into Hungarian plum growing. Acta Hort. 734:417-423.

Tóth, E. 1957. Analytical and morphological analysis of plum cultivars. Kertészeti Kutató Intézet Évkönyv 2:11-129. (in Hungarian).

Tóth, E. and D. Surányi. 1980. Plum. Mezőgazdasági Kiadó, Budapest, Hungary.

Tóth, M. 2013. Utilization of fruit cultivars originated from the Carpathian Basin, p. 119-135. In: M. Soltész (ed.). Hungarian fruit cultivars. Mezőgazda Kiadó, Budapest, Hungary (in Hungarian)

Tóth, M. and Zs. Szani. 2004. Traditional farming within the Carpathian basin - pomaceous fruits. Intl. J. Hort. Sci. 10:15-17.

Wünsch, A. 2009. Cross-transferable polymorphic SSR loci in Prunus species. Sci. Hort. 120:348-352.

Xuan, H., Y. Ding, D. Spann, O. Möller, M. Büchele, and M. Neumüller. 2011. Microsatellite markers (SRR) as a tool to assist in identification of European plum (Prunus domestica). Acta Hort. 918:689-692.

Yazici, K. and A. Sahin. 2016. Characterization of pomegranate (Punica granatum L.) hybrids and their potential use in further breeding. Turk. J. Agr. For. 40:813-824. 